PART II. PHYSICAL ACTIVITY OF SOCIAL AND PROFESSIONAL GROUPS DZIAŁ II. AKTYWNOŚĆ FIZYCZNA GRUP SPOŁECZNYCH I ZAWODOWYCH

\title{
TESTS ASSESSING UPPER LIMB FUNCTION AND THEIR USE IN HAND THERAPY FOR CHILDREN WITH HEMIPLEGIC CEREBRAL PALSY
}

\section{TESTY OCENIAJĄCE FUNKCJE KOŃCZYNY GÓRNEJ I ICH ZASTOSOWANIE W TERAPII RĘKI DZIECI Z MÓZGOWYM PORAŻENIEM DZIECIĘCYM POD POSTACIĄ HEMIPLEGII}

\author{
Monika Kadłubowska ${ }^{1(\mathrm{~A}, \mathrm{~B}, \mathrm{C}, \mathrm{D}, \mathrm{E})}$
}

${ }^{1}$ Department of Physiotherapy, John Paul II University of Applied Sciences in Biala Podlaska, Poland

Authors' contribution Wkład autorów:

A. Study design/planning zaplanowanie badań

B. Data collection/entry zebranie danych

C. Data analysis/statistics dane - analiza i statystyki D. Data interpretation interpretacja danych E. Preparation of manuscript przygotowanie artykułu F. Literature analysis/search wyszukiwanie i analiza literatury G. Funds collection zebranie funduszy

\section{Summary}

Cerebral palsy encompasses nonprogressive but evolving disorders, primarily motor, resulting from damage to the region of the central nervous system (CNS) during early development. Cerebral palsy occurs at a frequency of 1 in 500 newborns and is the leading cause of physical disability among children. Preterm birth is a major risk factor for cerebral palsy and more than half of children diagnosed with cerebral palsy are born prematurely. Factors predisposing a child to the development of cerebral palsy can be divided into prenatal, perinatal, and postnatal. Cerebral palsy can be divided into 4 main types: spastic, dyskinetic, ataxic, and mixed. This paper aims to highlight the need for hand therapy in children with cerebral palsy and the use of clinimetrics in pediatric therapy. The most common scales used to assess upper limb involvement are the Manual Ability Classification System (MACS) for children 4-18 years old with cerebral palsy, Zancolli classification, House classification, Assisting Hand Assessment (AHA) Test, Melbourne Assessment 2, Hypertonia Assessment Tool (HAT), Ashworth Scale, Modified Ashworth Scale, Modified Tardieu Scale, and general scales used to assess a child's gross and fine motor functioning. Finally, a sample hand therapy program for children with cerebral palsy was proposed.

Keywords: muscle spasticity, cerebral palsy, hemiplegia, rehabilitation, hand, child

\section{Streszczenie}

Mózgowe porażenie dziecięce to pojęcie obejmujące niepostępujące, ale ewoluujące zaburzenia, głównie ruchowe, będące następstwem uszkodzenia ośrodkowego układu nerwowego (OUN) we wczesnym stadium jego rozwoju. Mózgowe porażenie dziecięce występuje z częstością 1 na 500 noworodków i jest główną przyczyną niepełnosprawności fizycznej u dzieci. Głównym czynnikiem zagrożenia mózgowym porażeniem dziecięcym jest wcześniactwo, a ponad połowa dzieci z mózgowym porażeniem dziecięcym to dzieci urodzone przedwcześnie. Czynniki predysponujące do rozwoju mózgowego porażenia dziecięcego można podzielić na prenatalne, perinatalne oraz postnatalne. Mózgowe porażenie dziecięce można podzielić na 4 kategorie: spastyczną, dyskinetyczną, ataktyczną oraz mieszaną. Celem tej pracy jest zwrócenie uwagi na konieczność terapii ręki dzieci z mózgowym porażeniem dziecięcym oraz na stosowanie klinimetrii w terapii dzieci. Najbardziej powszechne skale stosowane do oceny kończyny górnej to: MACS - skala oceny możliwości manualnych dzieci z mózgowym porażeniem dziecięcym w wieku 4-18 lat, klasyfikacja Zancolli, klasyfikacja Housa, test AHA - Assisting Hand Assessment, skala Maelbourne Assessment 2, skala oceny hipertonii - HAT, skala Ashworth'a, zmodyfikowana skala Ashworth'a, zmodyfikowana skala Tardieu oraz ogólne skale stosowane do oceny motoryki dużej i funkcjonowania dzieci. Na końcu zaproponowany został przykładowy program terapii ręki dla dziecka z mózgowym porażeniem dziecięcym.

Słowa kluczowe: spastyczność mięśni, mózgowe porażenie dziecięce, hemiplegia, rehabilitacja, ręka, dziecko
Tables: 3

Figures: 19

References: 39

Submitted: 2021 Aug 23

Accepted: 2021 Oct 27

Kadłubowska M. Tests assessing upper limb function and their use in hand therapy for children with hemiplegic cerebral palsy. Health Prob Civil. 2022; 16(1): 63-81. https://doi.org/10.5114/hpc.2021.110455

Address for correspondence / Adres korespondencyjny: Monika Kadłubowska, Department of Physiotherapy, John Paul II University of Applied Sciences in Biala Podlaska, Sidorska 95/97, 21-500 Biała Podlaska, Poland, e-mail: m.kadlubowska@dyd.akademiabialska.pl, phone: +48 83 344 99 00, https://orcid.org/0000-00023403-7122

Copyright: (C) John Paul II University of Applied Sciences in Biala Podlaska, Monika Kadłubowska. This is an Open Access journal, all articles are distributed under the terms of the Creative Commons Attribution-NonCommercial-ShareAlike 4.0 International (CC BY-NC-SA 4.0) License (http://creativecommons.org/licenses/ by-nc-sa/4.0/), allowing third parties to copy and redistribute the material in any medium or format and to remix, transform, and build upon the material, provided the original work is properly cited and states its license. 


\section{Introduction}

Cerebral palsy is a group of disorders characterized by a nonprogressive but evolving injury to primarily the motor region of the central nervous system (CNS) during early development. Cerebral palsy, which occurs at a rate of 1 in 500 newborns, is the leading cause of physical disability in children [1,2]. The incidence of cerebral palsy is increased in children born with lower birth weights and greater immaturity. The increased survival rate of preterm babies has resulted in an increase in the incidence of cerebral palsy [3].

In more than $80 \%$ of cases, cerebral palsy is caused by brain lesions or malformations attributed to different periods of brain development. The extent and topography of the injury determines the clinical subtype of cerebral palsy and the presence and severity of associated disabilities [3].

Preterm birth is a major risk factor for cerebral palsy. More than half of children diagnosed with cerebral palsy were born prematurely [4]. Factors affecting the occurrence and causing damage to the CNS resulting in an increased risk of cerebral palsy can be divided into 3 periods: prenatal, perinatal, postnatal (Table 1).

Table 1. Factors that increase the risk of CNS injury

\begin{tabular}{|c|c|c|}
\hline Prenatal factors & Perinatal factors & Postnatal factors \\
\hline Congenital infections & Preterm birth & Head and CNS Injury \\
\hline $\begin{array}{c}\text { Teratogenic agents } \\
\text { (pharmaceuticals) }\end{array}$ & Hypoxia & Cardiac arrest \\
\hline $\begin{array}{c}\text { Vascular disorders (hypoxia, ischemia, } \\
\text { thrombosis) }\end{array}$ & Hyperbilirubinemia \\
\hline $\begin{array}{c}\text { Congenital fetal malformations } \\
\text { Alcohol consumption, maternal } \\
\text { nicotine smoking }\end{array}$ & $\begin{array}{c}\text { Complications of childbirth (placental } \\
\text { abruption, hematomas) }\end{array}$ & Neonatal convulsions \\
\hline Metabolic diseases of the mother & Hyperglycemia & \\
\hline Iodine deficiency & Perinatal infections & \\
\hline $\begin{array}{c}\text { Placental and other pregnancy } \\
\text { pathologies }\end{array}$ & bleeding) & \\
\hline
\end{tabular}

In addition to movement disorders, cerebral palsy is associated with sensory disturbances, sensory disorders, perceptual disturbances, behavioral disorders, mental developmental disorders, speech disorders, respiratory distress, chewing and swallowing disorders, spasticity or dyskinesia, muscle spasms, bone growth disorders, epilepsy, cognitive dysfunction, mirror movements [4,5].

In 2006, a study involving 431 children by Bax et al. was published in which researchers found correlations between the presence of cerebral palsy and changes in brain magnetic resonance imaging (MRI) images. Only $11.7 \%$ of children with cerebral palsy had a normal MRI image. Forty-two percent had damage to the brain's white matter associated with preterm birth (periventricular leukomalacia (PVL) and hemorrhage), and $12.8 \%$ had anomalies involving the basal nuclei of the brain. Other abnormalities identified on MRI were cortical and subcortical lesions (9.4\%), malformations (9.1\%), and cerebrovascular strokes (7.4\%). The remaining $7.1 \%$ of injuries were classified as other damages. Currently, to confirm a diagnosis of cerebral palsy, an MRI is recommended to determine the location and degree of damage to the developing brain. It is also helpful in predicting the child's future development $[4,5]$.

\section{Classifications of cerebral palsy}

The new definition of cerebral palsy has forced researchers to consider new classification criteria. The classifications are intended to help better understand the etiology and predict a child's development. On this basis, the following forms were identified:

- spastic - the dysregulation of muscle tone depends on the position and movement of separate body segments. The most common form with an incidence of $70-80 \%$;

- dyskinetic (dystonia and choreoathetosis) - characterized by a decrease in basal muscle tone and muscle rigidity, a small repertoire of movements, and the appearance of involuntary movements. The second most common form with an incidence of $10-20 \%$; 
- ataxic - mainly a disorder of balance, eye-hand coordination, and motor agility. This form occurs in $5-10 \%$ of patients with cerebral palsy;

- mixed - where one is unable to identify the main form of the disorder and different types of disorders occur simultaneously. About $5 \%$ of patients have this diagnosis [6].

\section{Classification of hemiplegia}

Type I - early malformation where the damage occurs in the first or second trimester of pregnancy. Otherwise, the pregnancy goes well and the baby is born on time.

Type II - prenatal damage characterized by PVL occurring at approximately 24-34 weeks of gestation. Preterm labor is very common with an average pregnancy length of 34 weeks.

Type III - perinatal damage occurring after 37 weeks or perinatally caused by hypoxia or ischemia of the brain.

Type IV - acquired damage that occurs between 4 weeks and 2 years of age. It is usually caused by trauma, cancer, infection, or ischemia of the brain.

Type $\mathrm{V}$ - hemidystonia damage can occur during the perinatal period as well as in early childhood. The cause is most often of vascular etiology such as a hemorrhagic or ischemic stroke involving the middle cerebral artery. Often the lesions are bilateral and asymmetric [7-9].

\section{Aim of the paper}

This paper aims to familiarize physical therapists, physicians, and other members of the treatment team with the classifications used in the assessment of the upper limb in children with cerebral palsy. Until now, the literature lacked papers describing the major scales used to assess the upper limb. These scales are used to access both the manual abilities of the affected hand, the functional capabilities of the radiocarpal joint and fingers, thumb positioning, cooperation of both hands in performing activities requiring the use of both hands, spasticity, and other functional characteristics. In this article, each scale was presented as well as a short description of the upper limb anatomy and biomechanics in children with hemiplegic cerebral palsy according to type. In addition, an explanation of what hand therapy should consist of and a sample hand therapy plan for a child with hemiplegic cerebral palsy is provided.

\section{An update on the state of knowledge about hemiplegia}

Currently, hemiplegia is the most common form of cerebral palsy (38\%), second only to diplegia in preterm infants (20\%). It is estimated that $70-90 \%$ of children with hemiplegia have a congenital form of the disease (the CNS damage occurred during pregnancy or up to the 4 th week of life), while $10-30 \%$ have the acquired form (the damage occurred between 4 weeks and the 3rd year of life) [7,8].

MRI is used to identify the changes in the CNS and to clarify the pathogenesis of hemiplegia. Based on the timing of lesion formation, the following lesions are observed on MRI:

- 1st and 2nd trimester - 16\% - abnormalities in brain development such as focal cortical dysplasia, pachygyria, lissencephaly, and unilateral schizencephaly;

- 3rd trimester - 36\% - periventricular white matter lesions such as PVL resulting from intraventricular hemorrhage;

- perinatal, neonatal period - 31\% - gray matter and cortical lesions such as damage to the basal nuclei and thalamus and damage caused by strokes;

- other MRI abnormalities - 7\% - lesions associated with hemiplegia such as periventricular lesions and malformations $[7,8]$.

The clinical picture of the upper limb depending on the type of hemiplegia:

- Type I - malformation, early:

» lowered shoulder girdle,

» shoulder joint in internal rotation,

» partially straightened elbow joint,

» forearm positioned in pronation,

» the radiocarpal joint in palmar flexion,

» thumb positioned in adduction,

» fingers straight at pip and dip joints, bent at mp joints; 
- Type II - prenatal:

» normal shoulder girdle,

» straight elbow joint,

» impaired forearm supination,

» the radiocarpal joint in palmar flexion,

» isolated work of fingers and thumb possible;

- Type III - perinatal:

» shoulder girdle in protraction,

» shoulder joint in adduction,

» elbow joint in flexion,

» the radiocarpal joint in ulnar adduction and palmar flexion,

» hand clenched into a fist with thumb adducted;

- Type IV - acquired:

» shoulder girdle in protraction,

» shoulder joint is positioned in adduction, flexion, and internal rotation,

» elbow joint in flexion,

» forearm positioned in pronation,

» the radiocarpal joint in ulnar adduction and palmar flexion,

» hand clenched into a fist with thumb adducte;

- Type V - hemidystonic:

» shoulder girdle in retraction,

» shoulder joint in flexion and adduction,

» elbow joint in flexion,

» forearm supination,

» semi-open hand [7-9].

\section{Mirror movements in children with hemiplegic cerebral palsy}

Mirror movements are involuntary movements of one part of the body that mirror the voluntary movements of the opposite, homologous body part. Mild mirror movements are common in preschool children but are often pathologic in children with hemiplegia. Although the mechanism of mirror movements is not fully understood and their etiology varies, however they likely reflect the abnormal organization of the developing motor system. The interplay between primary and secondary motor areas and the interhemispheric inhibition necessary for effective unilateral movements are disrupted.

To date, two neurophysiological mechanisms have been investigated to explain the neurophysiology of mirror movements in children with cerebral palsy: the ipsilateral corticospinal pathway projecting from the intact motor cortex to homologous muscles and co-activation of bilateral motor cortexes resulting from insufficient interhemispheric inhibition.

Mirror movements in the affected upper limb are indicative of ipsilateral reorganization, while they are the result of sensorimotor damage to the affected upper limb in the uninvolved upper limb [10].

\section{Hand therapy}

Abnormal motor development has a negative influence on hand development and therapy should be based mainly on the improvement of fine motor skills, i.e., precise movements of hands, palms, and fingers. Additionally, it is important to remember the manual skills essential for human interaction with the environment. Hands allow contact with other people, everyday objects, toys, etc. The successful use of one's hands is not only dependent on the child's manual abilities, but also requires correct posture, cognitive, and visual functions [11].

Each member of the therapy team working with the child's hands should be very familiar with a child's normal development, cognitive function development, and precision grip development. Before starting therapy on hand functions, it is important to access these other aspects of a child's development. Therapy always begins with a thorough diagnosis and evaluation of hand function. Many scales exist to help assess and describe hand function. This allows for the individual customization of a physiotherapy treatment program and the ability to monitor improvements with the program.

A combination of massage or fascial therapy with hand therapy is very effective. Therapy should begin by targeting structures responsible for large motor skills including the paraspinal muscles, suboccipital muscles, 
and entire shoulder girdle including the scapula. This should be done slowly and in a calm atmosphere to allow full relaxation to be achieved. This step should be performed for no less than 30 minutes. This should be followed by mobilization of the scapula, shoulder joint, opening of the thorax, mobilization of the intercostals of the forearm, and finally the opening of the hand. Once these structures have been adequately relaxed, the patient will be able to perform to their full potential during active exercises. These specific exercises are designed to increase shoulder joint range of motion (ROM), extension of the elbow joint, and improve the fine motor skills of the radiocarpal joint and hand, as well as increase the muscle strength of weakened muscle groups.

\section{Scales used to assess the manual abilities of people with cerebral palsy}

\section{Manual Ability Classification System (MACS)}

MACS - a scale for assessing the manual abilities of children between the ages of 4-18 years with cerebral palsy. This scale assesses how children with cerebral palsy use their hands when handling everyday objects. This scale evaluates the overall ability of the child to use objects thus it does not evaluate each hand individually, but rather collectively [12].

MACS uses 5 levels based on how the child handles objects:

I. Level 1 - performs activities easily and efficiently;

II. Level 2 - performs activities with difficulty, less speed, and less accuracy;

III. Level 3 - performs activities with difficulty, requires assistance from others or with individual modifications;

IV. Level 4 - performs activities with great difficulty and in an appropriate environment can initiate an activity but is unable to independently complete the task;

V. Level 5 - unable to perform even simple tasks.

\section{Zancolli Classification}

Another scale used for functional hand assessments is the Zancolli classification. This classification is used to evaluate hand function, taking into account wrist dorsiflexion, wrist extension, and finger extension. The Zancolli classification consists of 5 types:

1. wrist dorsiflexion is possible with fingers straight - 0-20 degrees (Figure 1);

2. wrist dorsiflexion is possible to less than 20 degrees with the fingers straight (Figure 2);

3. wrist dorsiflexion is possible when the fingers are flexed (Figure 3);

4. wrist dorsiflexion is not possible even with the fingers flexed (Figure 4);

5. wrist dorsiflexion and finger extension are not possible (Figure 5) [13,14].

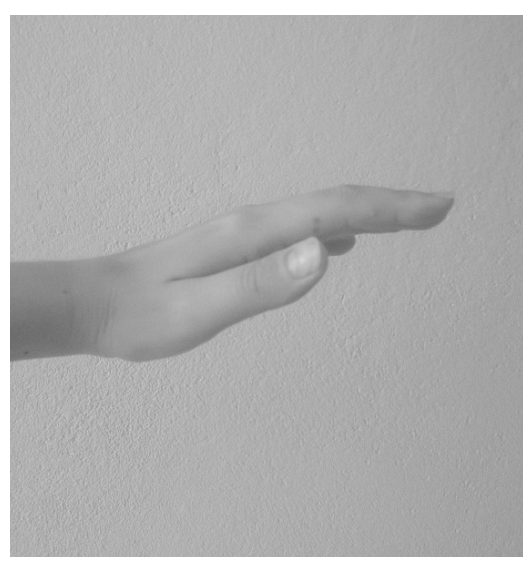

Figure 1. Wrist dorsiflexion with fingers extended 0-20 degrees

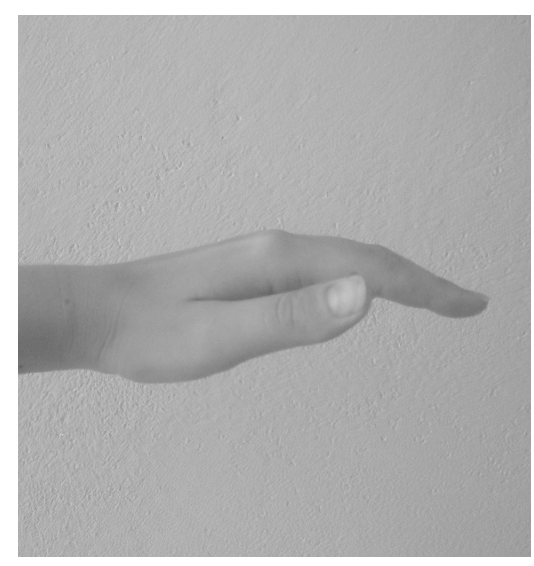

Figure 2. Wrist dorsiflexion with fingers straight less than 20 degrees

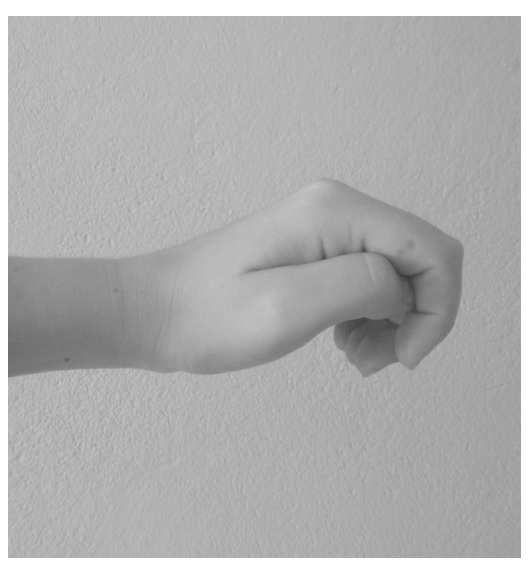

Figure 3. Wrist dorsiflexion when the fingers are flexed 


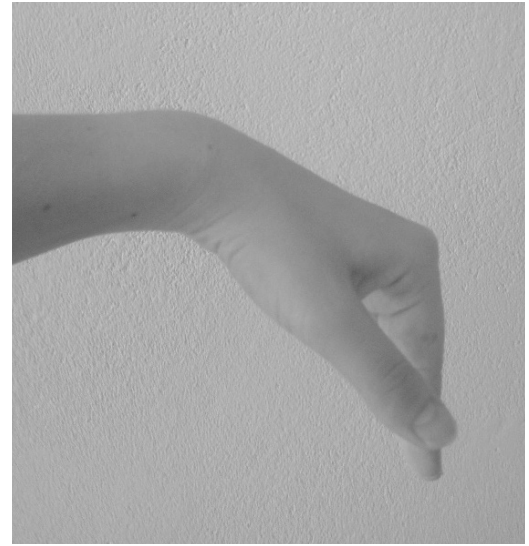

Figure 4. No wrist dorsiflexion with fingers flexed

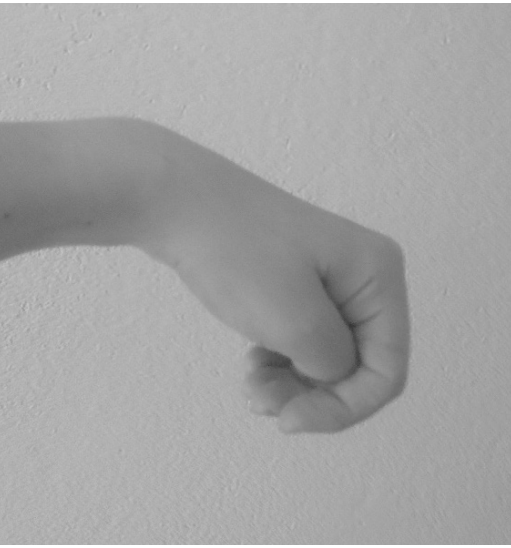

Figure 5. No wrist dorsiflexion or extension of the fingers

\section{House Classification}

The House classification is used to evaluate the function of the thumb in children with cerebral palsy. It consists of 4 types of thumb placement:

1. thumb in adduction (Figure 6);

2. thumb in adduction, flexed at the metacarpophalangeal joint (Figure 7);

3. thumb is dislocated at the metacarpophalangeal joint (Figure 8);

4. thumb is positioned in adduction and flexed at the metacarpophalangeal and interphalangeal joints (Figure 9) [15].

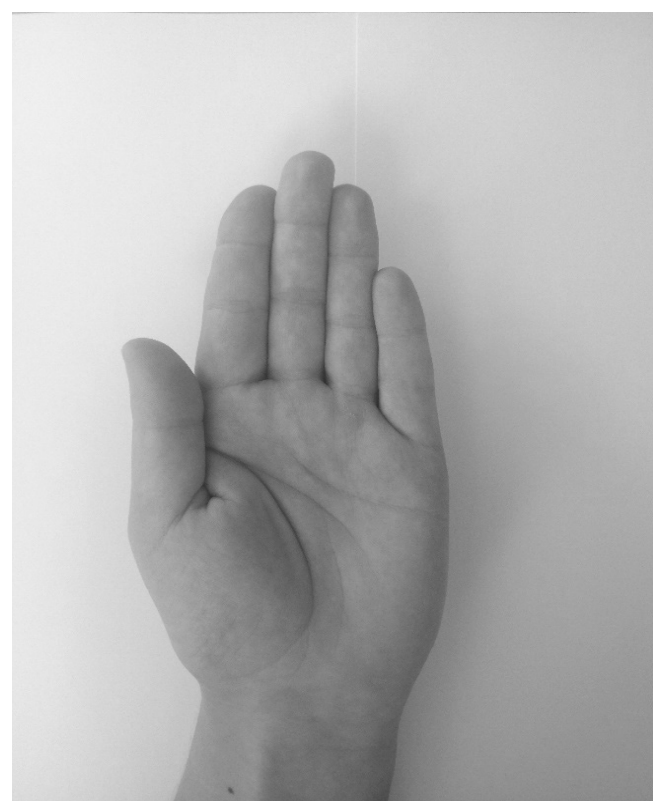

Figure 6. Thumb in adduction

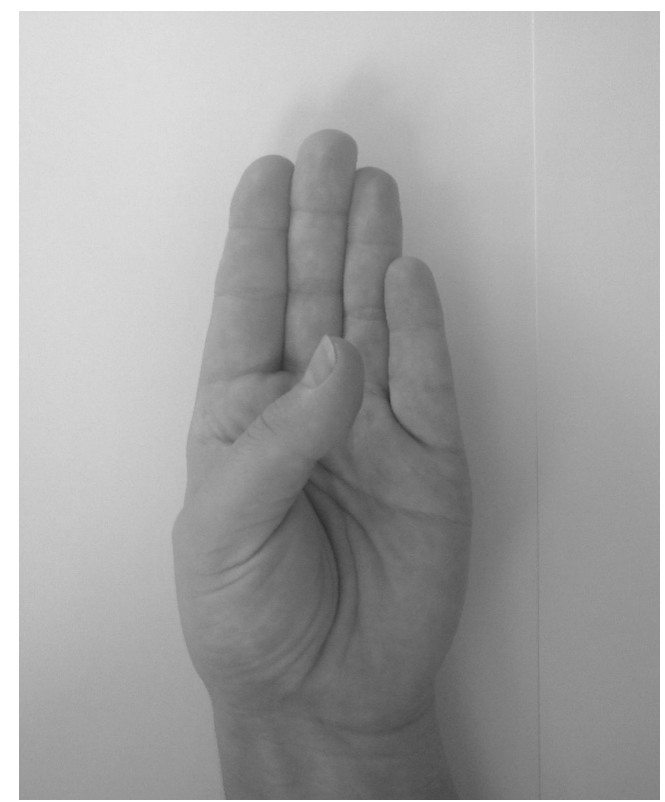

Figure 7. Thumb in adduction, bent at the metacarpophalangeal joint 


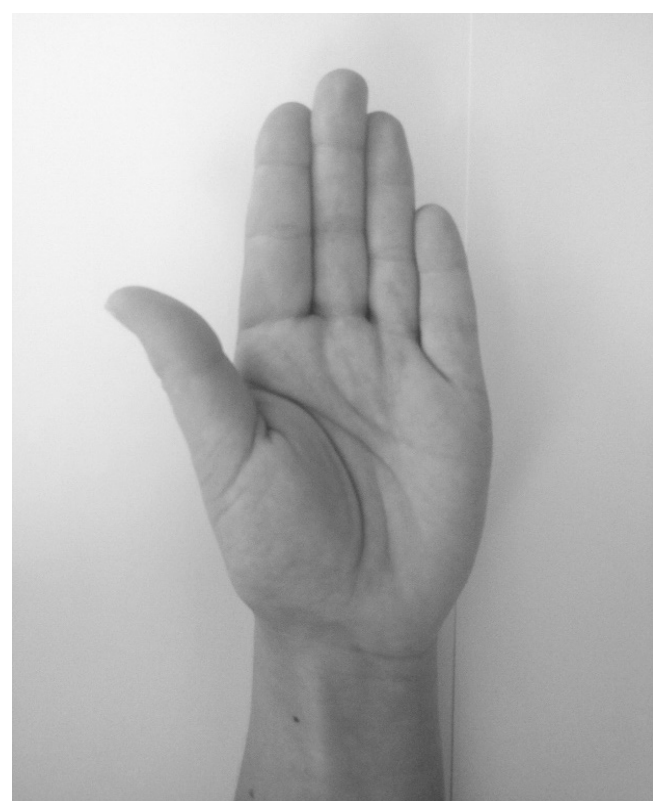

Figure 8. Thumb dislocated at the metacarpophalangeal joint

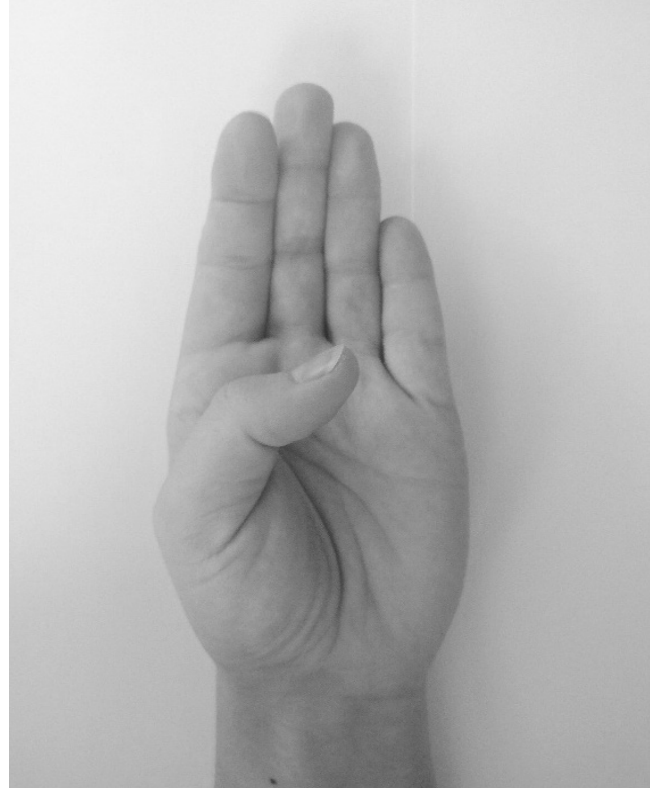

Figure 9. The thumb is adducted and flexed at the metacarpophalangeal and interphalangeal joints

\section{Assisting Hand Assessment (AHA) test}

When examining a patient with cerebral palsy, an assessment of the assisting hand may be performed. To do this one can utilize the AHA test, which describes how the child uses the paralyzed limb for activities requiring the use of both hands [16]. This test is performed in cerebral palsy patients with unilateral upper limb palsy and children with brachial plexus injuries. The AHA test is diagnostic and therapeutic in nature as it assesses the assisting hand's initial state of functioning and its functioning after therapy. It can be performed on children from 18 months to 12 years of age. It involves filming a child for 15 minutes while they play with standardized toys. The toys used can fit into one suitcase and are suitable for any age group. How a child plays with the toys is entirely up to the child. The test taker cannot interfere with how the child uses each item. The maximum score a patient can achieve is 88 points. The patient receives 4 points for each correctly completed task. Patients that fail to perform the task receive 1 point. Twenty-two activities are assessed e.g., grasping an object, placing an object in the preferred hand, coordination, etc. [16-18].

\section{Melbourne Assessment 2 (MA2)}

The MA2 scale is used for children aged 2.5 to 15 years old with neurological upper extremity dysfunction. The test consists of 14 test items that measure 4 aspects describing the quality of movement: ROM, precision, dexterity, fluidity.

The child is observed performing the following activities - reaching, grasping, releasing a grip, and manipulating easy everyday objects. Each measured element of movement are scored using a 3, 4, or 5 point scale and summed individually. The child's final score on the MA2 is presented as four separate scores, one for each element of movement measured. For better evaluation, the test is filmed [19].

The MA2 scale can provide information to:

- identify elements of a child's movement requiring intervention, such as limitations in active ROM and identification of muscles requiring surgical intervention;

- compare one child's performance with another during or after a specific therapeutic intervention;

- identify areas in need of therapy or use as justification for therapeutic intervention;

- evaluate changes in upper limb function before and after interventions (such as therapeutic, surgical, and neurological interventions);

- provide information to parents, teachers, and treatment team members about the child's progress [19]. 


\section{ROM testing}

Another important component in the examination of the upper limb in children with cerebral palsy is the examination of both passive and active ROM. The test should be performed using a goniometer or inclinometer. This easy method can be used to evaluate whether therapy provided by the physiotherapist is having the intended effect of increasing ROM.

By examining passive ROM, the severity of spasticity can be evaluated at the same time. In the upper limb, the flexors of the elbow joint are usually examined using these 3 scales: Ashworth scale, modified Ashworth scale, modified Tardieu scale.

The Ashworth scale is the most commonly used scale to measure spasticity in children. Subjective assessments evaluating muscle tone of individual muscle groups are performed with the patient in a relaxed supine position.

Scoring:

- grade 0: passive movement without increased muscle tone;

- grade 1: a slight increase in tension during passive movement causing a "hold" when moving the limb in the flexion-extension direction;

- grade 2: a more marked increase in tension during passive movement, but the limb still bends or straightens easily;

- grade 3: significant increase in tension making passive movements difficult to perform;

- grade 4: limb rigid in flexion or extension and passive movements are impossible [20,21].

In 1987, this scale was modified by introducing an additional 1+ category.

Modified Ashworth Scale:

- grade 0: passive movement without increased muscle tone;

- grade 1: a slight increase in muscle tone, manifested by resistance and release or a minimal increase in muscle tone at the end of a flexing or straightening movement;

- grade 1+: a slight increase in muscle tone, manifested by resistance and release followed by minimal resistance throughout the remainder (less than half) of the movement;

- grade 2: significant increase in muscle tone for most of the joint's ROM, but passive movement is easy to perform;

- grade 3: a marked increase in muscle tone during the entire range of passive movement and passive movements are difficult to perform;

- grade 4: the affected joint is impossible to move through passive flexion and extension movements [22].

In children with spastic cerebral palsy, a strong correlation is observed between the speed of a movement and ROM. Both Ashworth scales correlate poorly with the degree and type of muscle tone disorder, thus the modified Tardieu scale is more useful in these children.

The modified Tardieu scale involves moving the limb as in passive mobility testing. First, a very slow movement is made (V1) and its range is measured with a goniometer, then a passive movement is made at a rate corresponding to the descent of the limb segment under the influence of gravity (V2), and then the same movement is made at maximum speed (V3). When the movement is performed quickly, there is a stop response due to spasticity and the examiner measures the ROM again. The two ranges are then compared and if spasticity is present the difference will be more than 20 degrees. The first measurement - the stopping angle at movement V1 is interpreted as a restriction due to increased muscle and connective tissue stiffness. The second measurement - taken at the movement speed of V2 is an intermediate value. The third measurement - the stopping angle at movement V3 is subtracted from the first measurement and determines the angle of spasticity [23].

\section{Hypertonia Assessment Tool (HAT)}

This scale is used to differentiate the type of hypertonia - spasticity, dystonia, extrapyramidal rigidity, and mixed type. It is used in children from 4-19 years of age. Seven elements are examined, e.g., the appearance of involuntary movements in the evaluated limb after tactile stimulation of the distal body part, velocitydependent resistance to stretch, presence of a spastic "catch", and maintenance of limb position during passive movement (Table 2). The rating is $0-1$, with 0 being negative (the behavior does not occur) and 1 being positive (the behavior occurs) [24]. The final result is shown in Table 3. 
Table 2. HAT Hypertonia Assessment Tool

\begin{tabular}{|c|c|c|c|c|}
\hline No. & HAT Element & $\begin{array}{c}\text { Evaluation Guidelines } \\
\text { 0 - Negative } \\
1 \text { - Positive } \\
\end{array}$ & Result & $\begin{array}{c}\text { Type of } \\
\text { hypertonia }\end{array}$ \\
\hline 1. & $\begin{array}{l}\text { Appearance of involuntary movements } \\
\text { in the assessed limb after tactile } \\
\text { stimulation of the distal body part }\end{array}$ & $\begin{array}{l}\text { 0-No involuntary movements } \\
\text { 1-Observed involuntary movements }\end{array}$ & $\begin{array}{l}0 \\
1\end{array}$ & Dystonia \\
\hline 2. & $\begin{array}{c}\text { Appearance of involuntary movements } \\
\text { while performing a task }\end{array}$ & $\begin{array}{c}\text { 0-No involuntary movements } \\
\text { 1-Observed involuntary movements }\end{array}$ & $\begin{array}{l}0 \\
1\end{array}$ & Dystonia \\
\hline 3. & Speed-dependent tensile resistance & $\begin{array}{c}\text { 0-No increased resistance during fast } \\
\text { motion vs slow motion } \\
\text { 1-Increased resistance during fast } \\
\text { movement }\end{array}$ & $\begin{array}{l}0 \\
1\end{array}$ & Spasticity \\
\hline 4. & Presence of a spastic "catch" & $\begin{array}{c}\text { 0-No spastic "catch" } \\
\text { 1-Present }\end{array}$ & $\begin{array}{l}0 \\
1\end{array}$ & Spasticity \\
\hline 5. & $\begin{array}{c}\text { Constant resistance to passive } \\
\text { stretching }\end{array}$ & $\begin{array}{c}0 \text {-Constant resistance not observed } \\
\text { 1-There is constant resistance }\end{array}$ & $\begin{array}{l}0 \\
1\end{array}$ & Stiffness \\
\hline 6. & $\begin{array}{l}\text { Increase in tension with movement of } \\
\text { distal parts }\end{array}$ & $\begin{array}{c}\text { 0-No increase in tension during targeted } \\
\text { movement } \\
\text { 1-Increase in tension during targeted } \\
\text { movement }\end{array}$ & $\begin{array}{l}0 \\
1\end{array}$ & Dystonia \\
\hline 7. & $\begin{array}{l}\text { Maintaining limb position during passive } \\
\text { movement }\end{array}$ & $\begin{array}{l}0 \text {-Limb returns to starting position } \\
\text { 1-The limb remains in the end position }\end{array}$ & $\begin{array}{l}0 \\
1\end{array}$ & Stiffness \\
\hline
\end{tabular}

Table 3. HAT score for hypertonia

\begin{tabular}{|c|l|c|c|}
\hline Dystonia & Positive (1) in at least one test item 1, 2, or 6 & Yes & No \\
\hline Spasticity & Positive (1) in at least one test item 3 or 4 & Yes & No \\
\hline Stiffness & Positive (1) in at least one test item 5 or 7 & Yes & No \\
\hline Mixed type & Presence of 1 or more subgroups (spasticity, dystonia, rigidity) & Yes & No \\
\hline
\end{tabular}

\section{Other scales}

When examining a child with cerebral palsy muscle strength should also be assessed (Lovett scale) in addition to the above tests. Because these children have spasticity and lack movement selectivity, it is sometimes difficult to test muscle strength using the Lovett scale. Sometimes a rough assessment of muscle strength by observing the child to see if they can perform a few squats or forearm supination is sufficient.

To assess movement selectivity, a 3-grade modified Trost scale is used:

1. joint movement is only possible with total synergy;

2. partially isolated movement is possible (e.g., the beginning of the movement is isolated and then flexion or extension synergy is activated);

3. a completely isolated movement from the beginning to the end of ROM [25].

Additional aspects that can be included in the evaluation are the presence of skeletal deformities, balance and coordination, and the child's functional assessment.

Various scales can be used for the functional assessment and to measure the progress of physiotherapy treatments. Commonly used scales include:

- GMFM scale (66 or 88) - motor function assessment,

- Canadian Occupational Performance Measure (COPM) - self-perceived functioning assessment,

- Toddler activities - assessment of preschool skills,

- Functional Independence Measure for Children (WEEFIM) scale to measure functional independence,

- Pediatric evaluation of disability inventory (PEDI) - assessment of functional capacity,

- PedsQL - assessing the child's motor, mental, school function, and social status,

- Pediatric Quality of Life Inventory - Pediatric Quality of Life Questionnaire [4,26]. 


\section{Discussion}

Many authors have addressed the validity of using clinimetrics in the treatment of children with cerebral palsy. In 2006, Eliasson et al. published an article validating the results of the MACS scale [27]. The validation was achieved using the experience of a group of experts, a review of the literature, and a thorough analysis of children across the spectrum of functioning. Parents and therapists were interviewed about the level and description of functioning. Reliability was tested between pairs of therapists treating 168 children (70 female, 98 male; with hemiplegia $(n=52)$, diplegia $(n=70)$, tetraplegia $(n=19)$, ataxia $(n=6)$, dyskinesia $(n=19)$, and unspecified palsy $(n=2))$ aged 4 to 18 years and between 25 parents and their child's therapists. The results of the study proved the MACS to have good validity and reliability. The correlation coefficient between therapists was $0.97(95 \%$ confidence interval 0.96-0.98) and between parents and therapist was 0.96 (0.89-0.98), indicating excellent agreement. A similar study was conducted in 2006 by Morris and Kurinczuk [28]. This study aimed to determine the reliability of family and professional assessments of the manual skills of children with cerebral palsy using MACS. The study reported excellent agreement between families and professionals in more than $50 \%$ of the children. The probability-adjusted concordance rates ranged from a kappa value of 0.3 to 0.5 , and the reliability coefficients ranged from an ICC value of 0.7 to 0.9 . The rate of agreement and reliability between families and professionals was the same as between different professionals. These studies demonstrate MACS to be a reliable method for communication about the manual skills of children with cerebral palsy. Similar results were also achieved in a 2010 study by Öhrvall et al. that was published in the Scandinavian Journal of Occupational Therapy [29]. In 2015, Jeevanantham and colleagues reviewed the literature supporting the reliability, validity, and stability of the MACS [30]. They confirmed that MACS can be used as a standard classification system for children with cerebral palsy to evaluate their manual abilities. MACS can be reliably used in children between the ages of 4-18 and adults aged 18-24 years [30].

Similar studies have been conducted using the MA2. In 2017, Wang et al. examined the psychometric and clinimetric properties of the MA2 questionnaire. The results of this study proved MA2 to have robust psychometric and clinimetric properties and to be an adequate scale for research and clinical purposes [31].

In 2013, Bover evaluated the AHA scale, pointing out that there is no manual available with clear instructions on how the measurements should be assessed. She concluded that having such instruction would make the scale accessible to a wider audience. She also included two reasons for measurement in her conclusions. First, to make child-specific decisions, and second, to evaluate the effectiveness of the intervention strategy [32].

Similar results have been obtained by other researchers who have validated the effectiveness of individual scales. These authors also stressed the importance of clinimetrics to evaluate the effectiveness of physiotherapy interventions and to assess a patient's functional status [33,34].

\section{Example of a hand therapy plan for a child with hemiplegic cerebral palsy}

The sample therapy plan was developed based on scientific reports evaluating the effectiveness of bimanual exercises in children with hemiplegic cerebral palsy $[35,36]$. The therapy was based on the principles of NDTBobath neurodevelopmental therapy, which is effective in controlling spasticity in children with cerebral palsy [37] and improving motor function [38,39].

Preparation of structures and mobilizations of the scapula, shoulder joint, and chest according to the NDT-Bobath concept

1. One of the first elements to perform during therapy is scapular mobilization (Figure 10). When performing scapular mobilization, an emphasis should be placed on the mobility of the scapula in each direction, especially in the caudal and medial directions. 


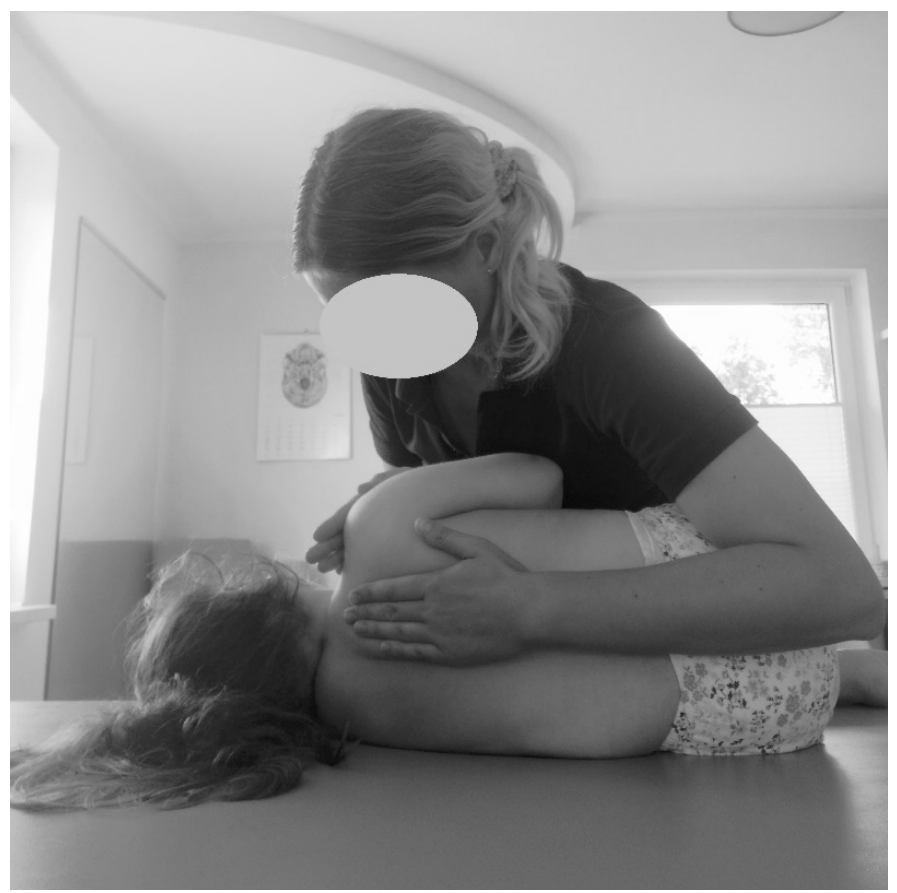

Figure 10. Scapular mobilization

2. Once adequate scapular mobility has been achieved, assisting with pressure techniques should be performed to provide a lot of sensory information to help the patient learn the new ROM. Pressure should be applied both distally (about the shoulder girdle) and proximally (to the knuckle of the hand) (Figure 11).

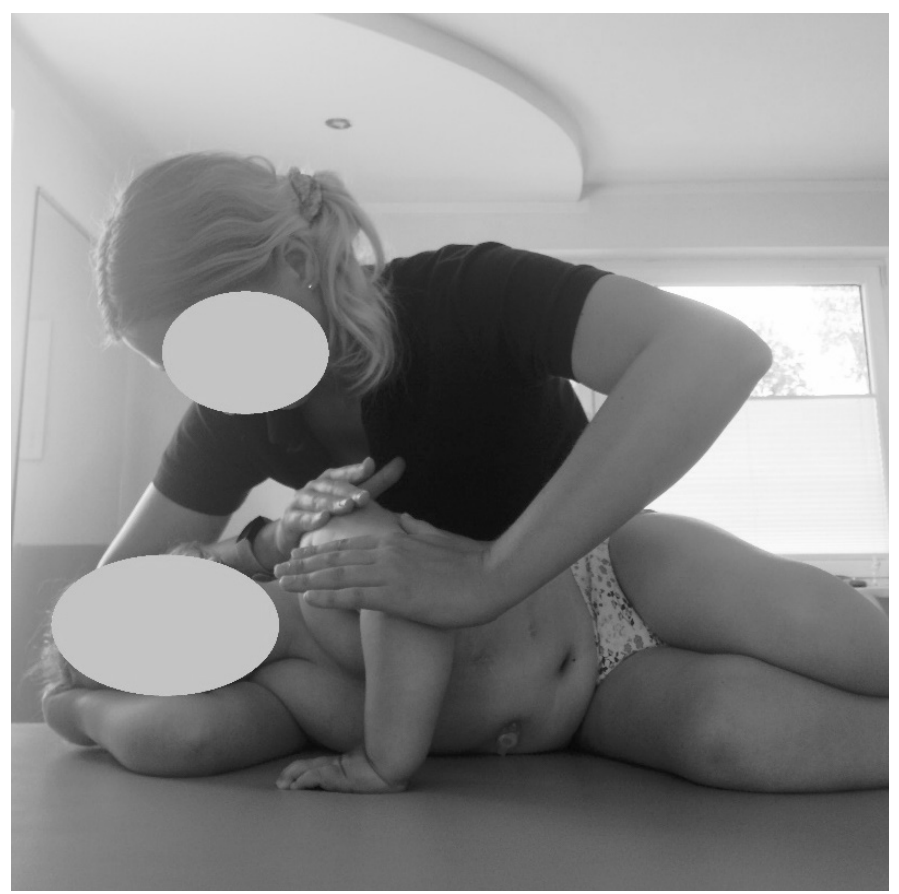

Figure 11. Support with pressure techniques

3. As a next step to reinforce the new ROM and to show the child the possibilities of his/her hand, exercises through play are introduced. With the scapula positioned pericentrally and caudally the child, plays with a car, rolls a ball, etc. 
4. After mobilizing the scapula, the next large structure to mobilize before therapy of the hand is the shoulder joint. It should begin with mobilization according to the NDT-Bobath concept, in every direction, keeping in mind that children with cerebral palsy habitually position this joint cranially and ventrally.

5. To increase the ROM of the shoulder joint, the ROM should be checked and if a limitation is found, an attempt should be made to increase the ROM. The patient lies on their back as the therapist brings the upper limb above the patient's head and then rotates the upper limb inward and applies pressure (compression) through the elbow toward the shoulder joint. The therapist then bends the elbow joint resting the hand on the ground (it should be placed behind the head) so that the fingers are pointing to the head, and again applies pressure (compression) through the elbow joint toward the shoulder joint and then the hand.

6. The next step in preparation for proper hand therapy is to open the chest. In the supine position, the therapist places their hands on the chest with one finger under and the others over the collarbone. The therapist then moves their fingers toward the shoulder joints opening the chest. Chest opening can also be performed with a ball - the therapist places a large, soft ball on the patient's chest, presses down from above, and moves it across the chest.

7. Mobilization of the forearm interosseous membrane can be performed with the patient in either a seated position in front of the therapist or in the supine position. The forearm should be supported on a soft ball or the therapy table. The therapist grasps the child's forearm in both hands, or one hand, if the child is small. Mobilization is then performed in different directions, and the goal is to relax the membrane and increase supination of the forearm. The following movements should be performed: breaking through (S) - the therapist brings their two thumbs together alternately; stretching the membrane across its fibers - the therapist places their thumbs on the distal part of the forearm and directs their thumbs proximally toward the elbow joint; stretching along the fibers - the thumbs are on the ventral part of the forearm and point outward, laterally and medially (Figure 12).

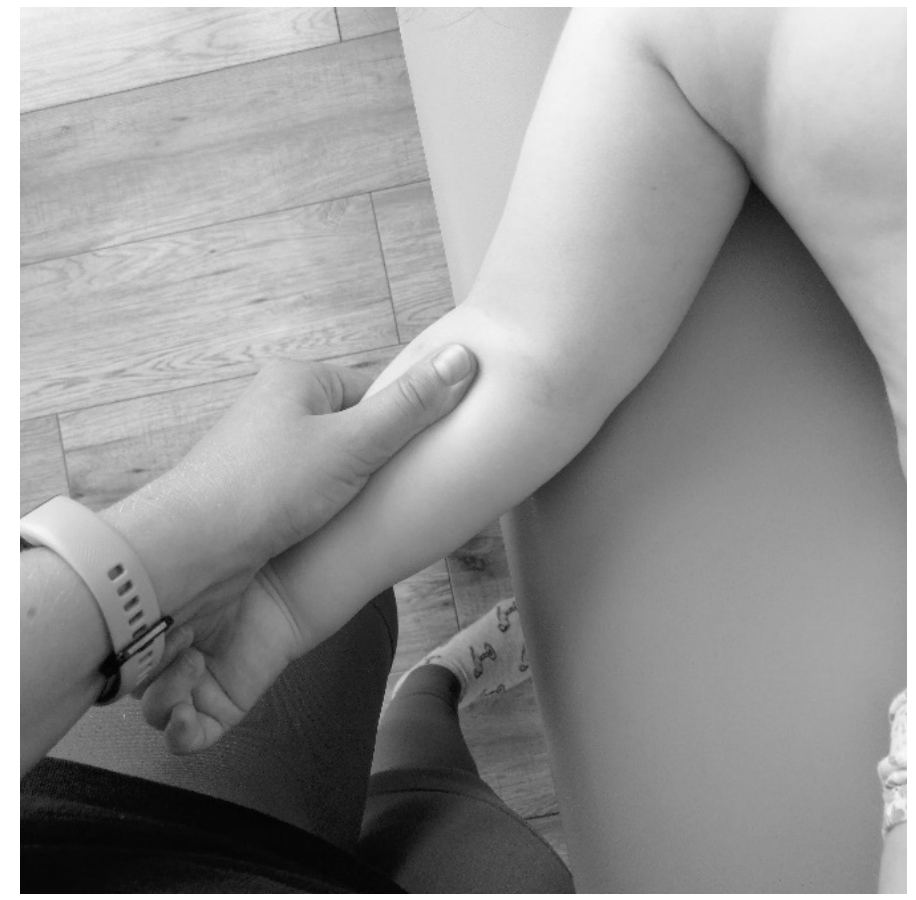

Figure 12. Mobilization of the interosseous membrane of the forearm.

8. Opening hands. In most patients with cerebral palsy, the procedure should begin with thumb release and focus on the painful areas around the thumb such as the carpometacarpal joint and the abductor pollicis brevis, adductor pollicis, flexor pollicis brevis, and opponens pollicis muscles (Figure 13). Additionally, perform manual relaxation of the fascia and muscles of the palm and dorsal side of the hand along with the metacarpophalangeal joints. The therapist uses their thumb to relax the intercostal spaces on the palm and then on the back of the hand. Next, grasp between the thumb and index finger and stretch each finger laterally then palmarly and dorsally. 


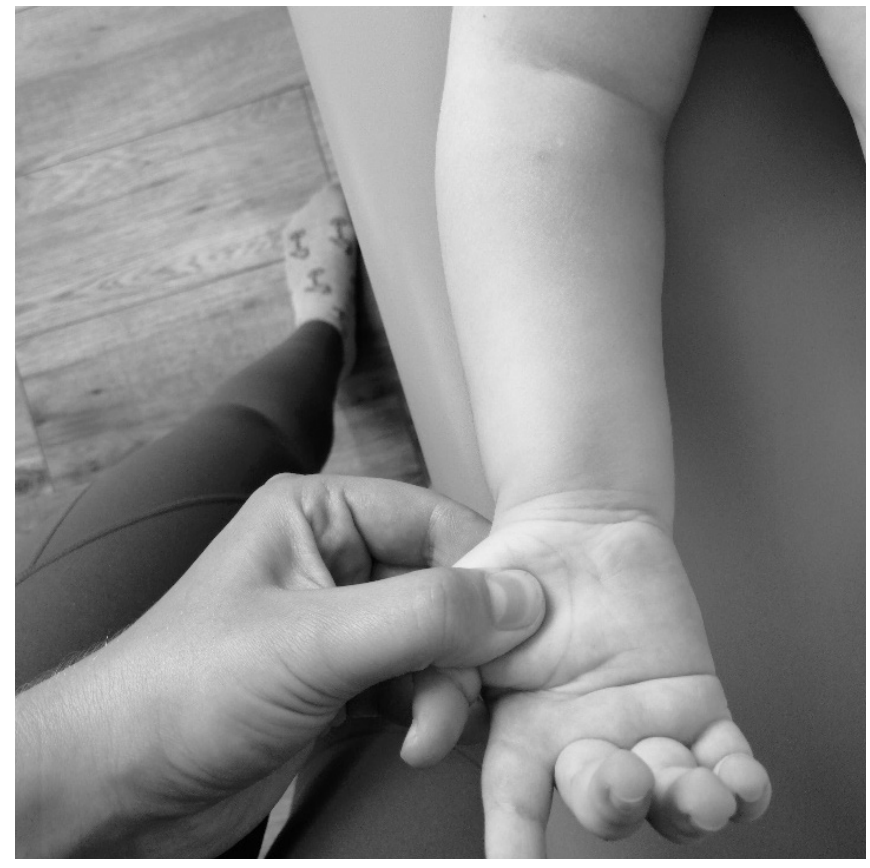

Figure 13. Opening hand

\section{Exercises to increase shoulder mobility and elbow joint extension}

1. Using a roller, the patient lies on their stomach with bags lying in front of them. The child's task is to grab the bags with one hand and then with the other. By extending the affected arm, the child works to increase flexion of the shoulder joint. Reaching with the unaffected arm works to increase muscle strength and deep sensation in the affected arm (Figure 14).

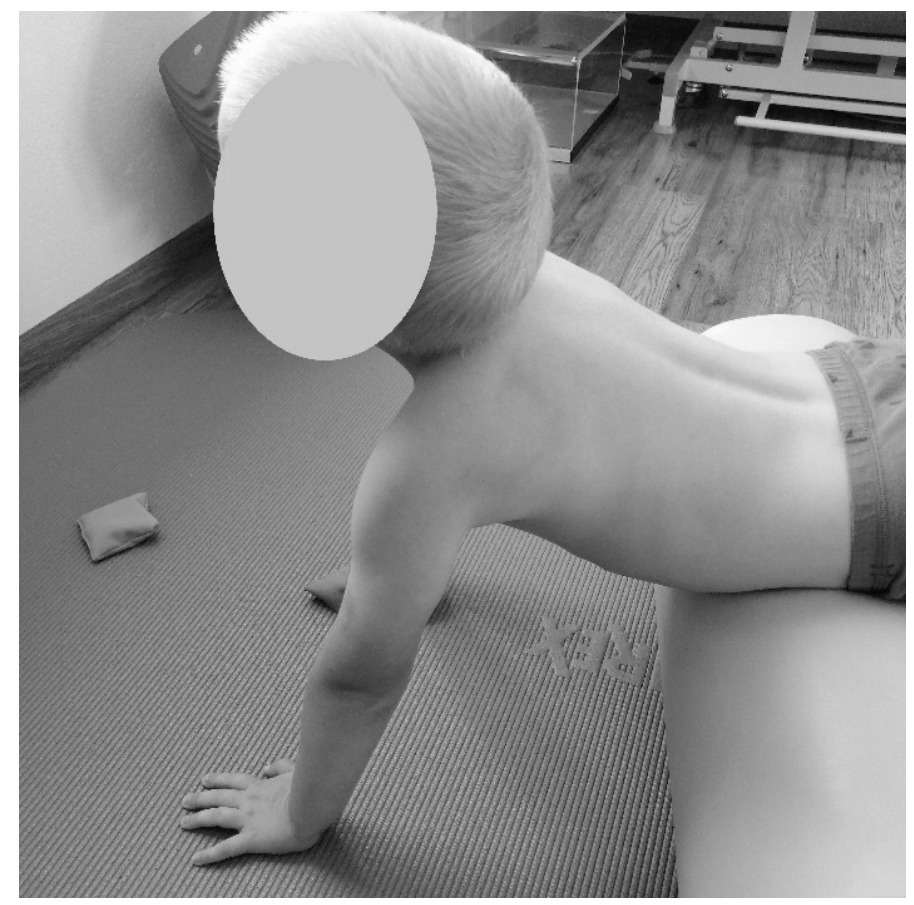

Figure 14. Exercise 1

2. Using a roller, the patient lies on their stomach holding their hand on a piece of paper, diaper, or cloth. Their task is to move the piece of material forward and backward. 
3. The patient sits perched on a roller and sticks suction cups to a mirror in front of them. This exercise increases extension of the elbow joint and allows the child to practice proper grip. Additionally, when the child reaches for the suction cup, attention should be paid to improving the rotation of the thoracolumbar area (Figure 15).

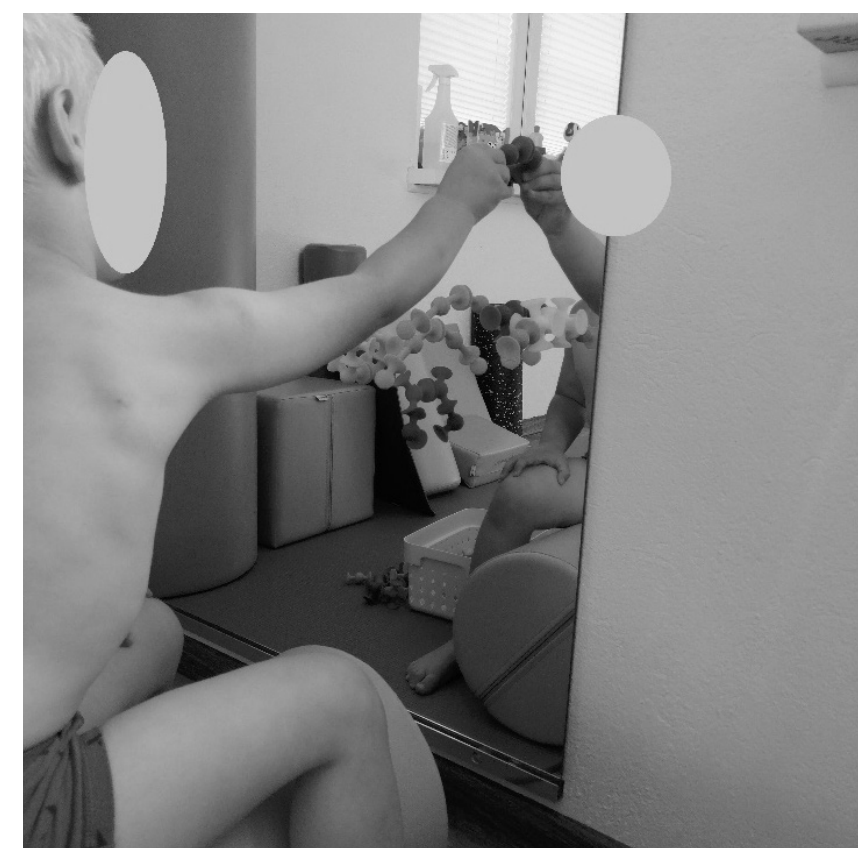

Figure 15. Exercise 3

4. With the patient sitting across a roller, the therapist passes a bag to the child from the side and back. When grasping an object, the child tries to increase the flexion of their shoulder joint and introduce rotation in the thoracolumbar area. The child then throws the bag into a basket in front of them to increase the extension of the elbow joint and flexion of the shoulder joint.

5. With the child standing in front of a wall, they attempt to hold a ball and roll the ball overhead alternating hands. Both hands must be in contact with the ball at all times (Figure 16).

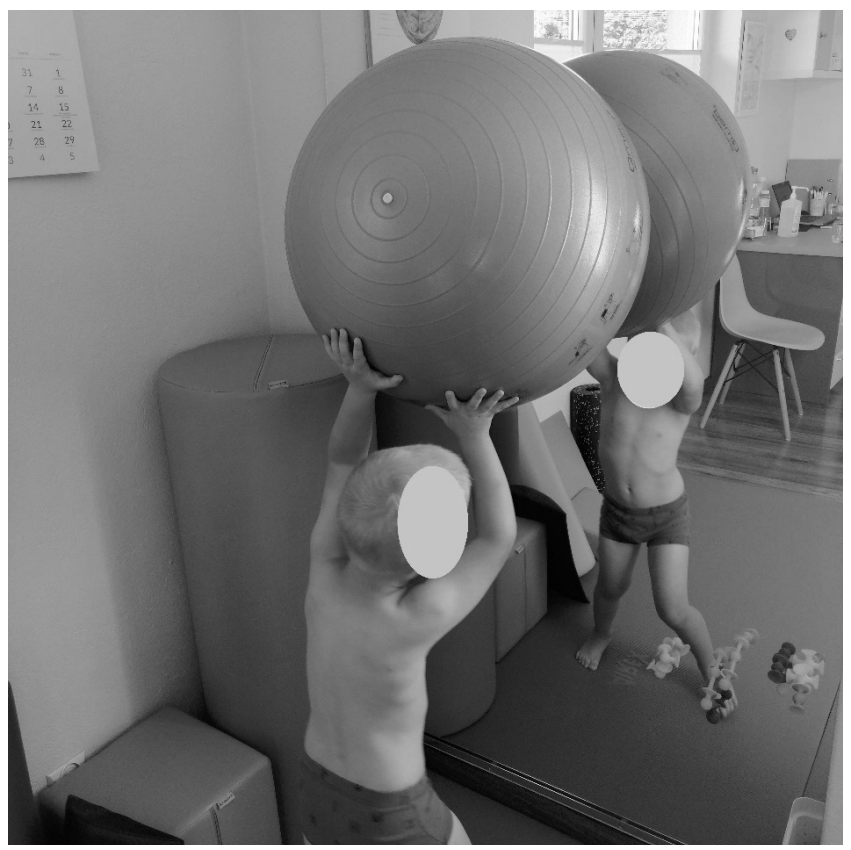

Figure 16. Exercise 5 
6. The child stands holding a ball above their head and tries to throw the ball with both hands from behind their head. This will help to reinforce the improved extension of the shoulder joint already achieved. In addition, the patient learns to swing their trunk backward and put weight on their heels.

7. If a child can maintain linearity, have the child sit on the floor with feet slightly apart. If unable to maintain linearity, have the patient sit on a roller or chair. In this exercise, their task is to catch fish. This game exercises hand-eye coordination and improves arm and elbow joint extension. In addition, precision grip and motor planning are practiced.

Fine motor skill exercises - wrist and hand

1. Unscrewing a bottle cap. The child is given a variety of containers with caps. The child's task is to unscrew the caps. Plastic bottles with large caps, jars, and $1.5 \mathrm{l}$ bottles can be used for therapy (Figure 17).

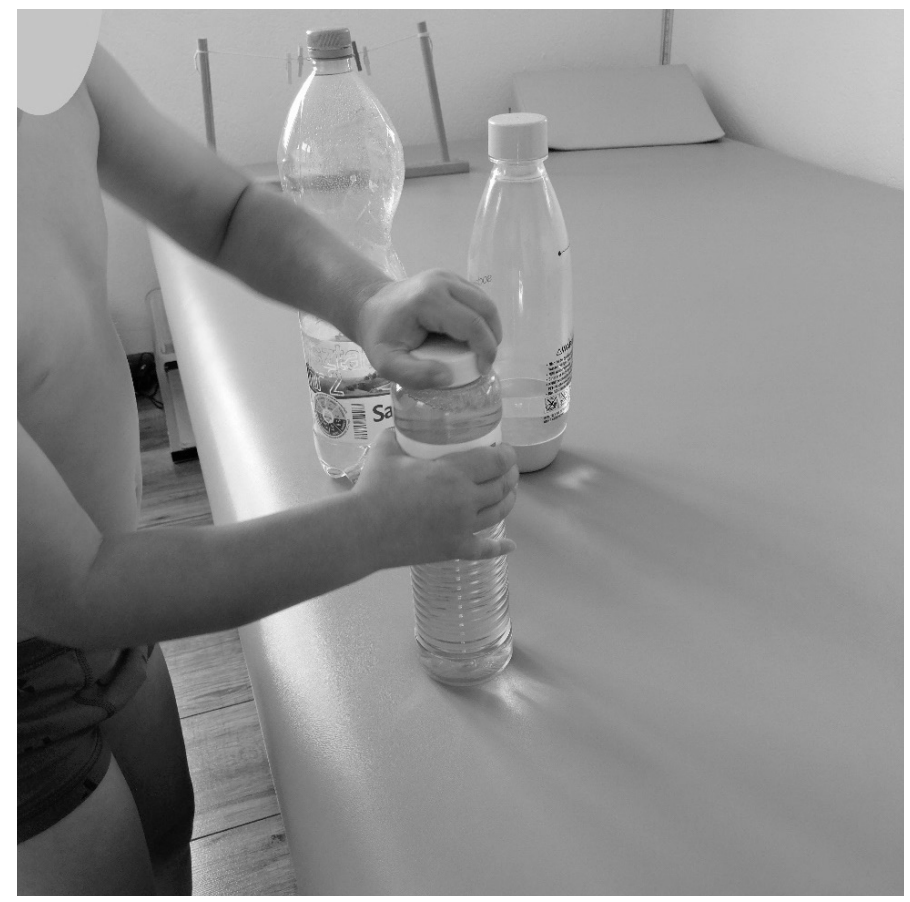

Figure 17. Unscrewing the cap

2. The child sits on a roller or chair with their forearms resting on the table. The therapist places an object on the back of their hand or forearm. The child's task is to knock down the object working to increase supination of the forearm.

3. The Sudoku Game. The child sits on a roller or chair with their forearms resting on the table. During this game, the child uses precision grasp to pick a tablet and place it in the correct small square which also improves hand-eye coordination.

4. Weaving string through small holes located along the periphery of a picture such as a panda. Once again, precision grip, hand-eye coordination, and extension of the elbow and shoulder joints are practiced (Figure 18). 


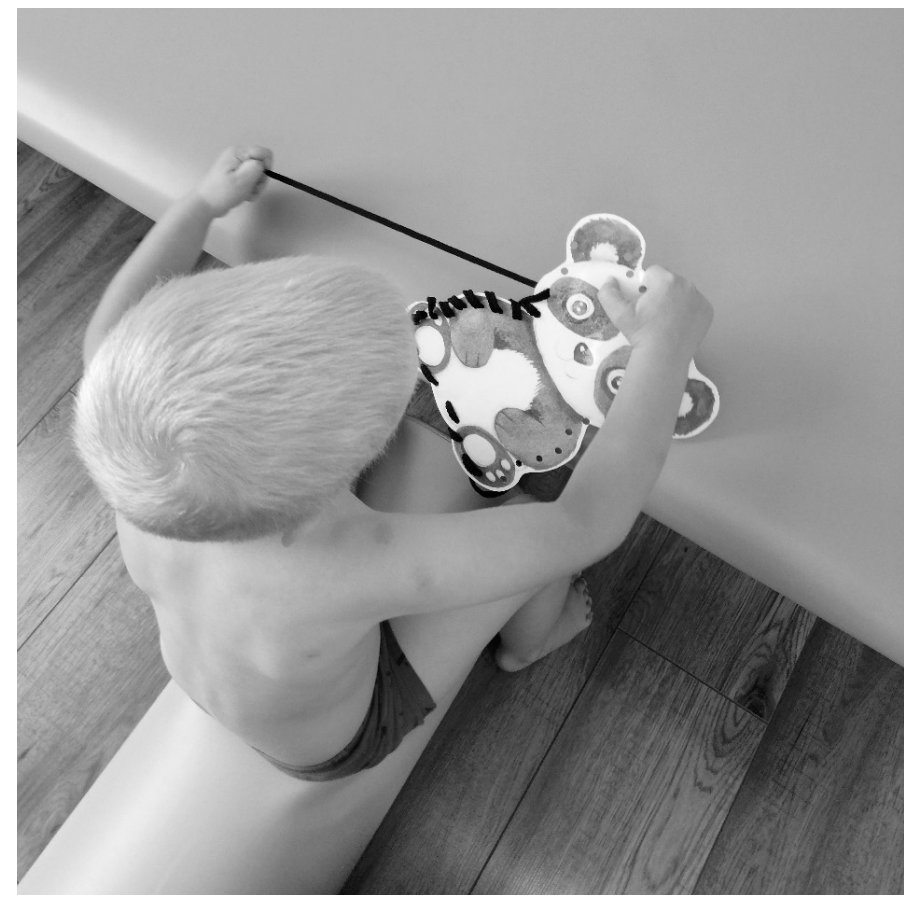

Figure 18. Threading a string through small holes along the periphery of a printed picture

5. Buttoning. To start, a sweatshirt with buttons is placed in front of the child so that he or she can manipulate it freely. The child then puts on the sweatshirt and is asked again to do the buttons.

6. A game of picks. Through play, the child exercises precision grip and hand-eye coordination.

7. Pinning of paperclips. The child pins clothes to a string using a paper clip (Figure 19).

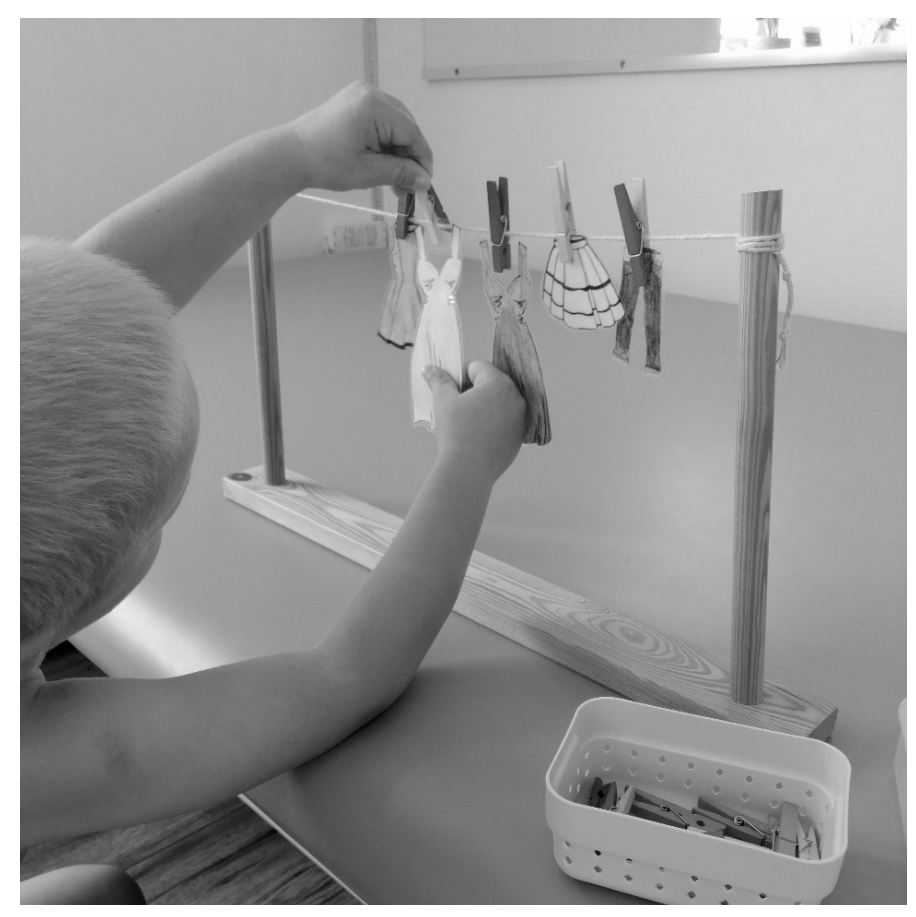

Figure 19. Pinning of paperclips 


\section{Conclusions}

To conduct reliable clinimetrics, knowledge of scales and tests that assess upper limb function are required. There are now several scales available that can be used to objectively determine the degree of function of the upper extremities. The most common are the MACS scale, Zancolli classification, AHA test, House classification, and MA2 scale. In addition to them, the Ashworth scale, modified Ashworth scale, modified Tardieu scale, and HAT can be used to assess the degree of spasticity.

The following scales are also used to comprehensively assess children with cerebral palsy: GMFM scale (66 or 88) - motor function assessment, COPM - self-perceived functioning assessment, Toddler activities - preschool skills assessment, WEEFIM - functional independence measurement scale, PEDI - functioning assessment, PedsQL - motor, mental, school and social status assessment, and Pediatric Quality of Life Inventory -Pediatric Quality of Life Questionnaire [2,4,5].

It is not necessary to use all of the scales on every patient, but by knowing the most important ones, each therapist can select the 2 to 3 most relevant scales to achieve their therapeutic goals.

It is also important to note that working with cerebral palsy patients requires a multidimensional approach to therapy. Additionally, it is important not only to rehabilitate daily but also to monitor the progress of therapy. A patient who sees even the smallest results of hard work will be much more likely to participate in the therapy plan. This is why it is important for physiotherapists, occupational therapists, and all members of the treatment team working with cerebral palsy patients to know and use scales and questionnaires to assess upper limb function. The measurement tools identify areas of concern allowing an effective treatment program to be planned. In addition to improving individual treatment outcomes, this will also standardize how cerebral palsy patients are tested and evaluated.

\section{Disclosures and acknowledgements}

The author declares no conflicts of interest with respect to the research, authorship, and/or publication of this article. This work was funded by the author.

\section{References:}

1. Rosenbaum P, Paneth N, Leviton A, Goldstein M, Bax M, Damiano D, et al. A report: the definition and classification of cerebral palsy. Developmental Medicine and Child Neurology. 2007; 49(Suppl.109): 8-14.

2. Stanley FJ, Blair E, Alberman E. Cerebral palsies: epidemiology and causal pathways. London: MacKeith Press; 2000. p. 251.

3. Krageloh-Mann I, Cans C. Cerebral palsy update. Brain \& Development. 2009; 31: 537-544. https://doi. org/10.1016/j.braindev.2009.03.009

4. Gajewska E. [The new definitions and functional scales used in children with cerebral palsy]. Neurologia Dziecięca. 2009; 35: 67-71 (in Polish).

5. Robertson CM, Watt MJ, Yasui Y. Changes in the prevalence of cerebral palsy for children born very prematurely within a population-based program over 30 years. JAMA. 2007; 297: 2733-2740. https://doi.org/10.1001/jama.297.24.2733

6. Pidcock FS, Hayakawa K, Yamori Y, Shikata Y, Kanda T. Motor outcome differences between two groups of children with spastic diplegia who received different intensities od early onset physiotherapy followed for 5 years. Brain \& Development. 2004; 26(2): 118-126. https://doi.org/10.1016/S0387-7604(03)00111-6

7. Jaspers E, Byblow WD, Feys H, Wenderoth N. The corticospinal tract: a biomarker to categorize upper limb functional potential in unilateral cerebral palsy. Front. Pediatr. 2015; 3: 112. https://doi.org/10.3389/ fped.2015.00112

8. Cioni G, Sgandurra G, Muzzini S, Paolicelli PB, Ferrari A. The spastic forms of cerebral palsy. Cham: Springer; 2010.

9. Feys H, Eyssen M, Jaspers E, Klingels K, Desloovere K, Molenaers G, et al. Relation between neuroradiological findings and upper limb function in hemiplegic cerebral palsy. Eur J Paediatr Neurol. 2010; 14(2): $169-177$. https://doi.org/10.1016/j.ejpn.2009.01.004

10. Eyre JA. Corticospinal tract development and its plasticity after perinatal injury. Neurosci Biobehav Rev. 2007; 31: 1136-1149. https://doi.org/10.1016/j.neubiorev.2007.05.011

11. Figueiredo PRP, Mancini MC, Feitosa AM, Teixeira CMMF, Guerzoni VPD, Elvrum AKG, et al. Handarm bimanual intensive therapy and daily functioning of children with bilateral cerebral palsy: 
a randomized controlled trial. Developmental Medicine and Child Neurology. 2020; 62(11): $1274-1282$. https://doi.org/10.1111/dmcn.14630

12. Eliasson AC, Rosbald B, Krumlinde-Sundholm L. The Manual Ability Classification System (MACS) for children with cerebral palsy: scale development and evidence of validity and reliability. Developmental Medicine and Child Neurology. 2006; 4B: 549-554. https://doi.org/10.1111/j.1469-8749.2006.tb01313.x

13. Bingol $H$, Kerem Gunel $M$. The effects of hand deformity on upper-limb function and health-related quality of life in children with spastic hemiplegic cerebral palsy. Hand Surgery and Rehab. Forthcoming 2021. https://doi.org/10.1016/j.hansur.2021.08.009

14. Park ES, Sim EG, Rha DW. Effect of upper limb deformities on gross motor and upper limb functions in children with spastic cerebral palsy. Research in Developmental Disabilities. 2011; 32(6): 2389-2397. https://doi.org/10.1016/j.ridd.2011.07.021

15. House JH, Fidler MO, Gwathmey LJ. A dynamic approach to the thumb-in-palm deformity in cerebral palsy: evaluation and results in fifty-six patients. The Journal of Bone and Joint Surgery. 1981; 63: 216-225. https://doi.org/10.2106/00004623-198163020-00006

16. Paczkowska A, Szmalec J, Krumlinde-Sundholm L, Zethraeus BM, Marcinkowski JT. [Dominant and assisting hand in diagnosis of a child with upper limb dysfunction - to optimize rehabilitation]. Hygeia Public Health. 2015: 50(1): 21-25 (in Polish).

17. Krumlinde-Sundholm L, Eliasson AC. Development of the assisting hand assessment: a rasch-built measure intended for children with unilateral upper limb impairments. Scandinavian Journal of Occupational Therapy. 2003; 10: 16-20. https://doi.org/10.1080/11038120310004529

18. Krumlinde-Sundholm L, Holmefur M. [Manual kids assisting hand assessment. $\beta$-version 5.0, English-Polish. Score sheet]. Ostróda; 2014 (in Polish).

19. Spirtos M, O’Mahony P, Malone M. Interrater reliability of the Melbourne Assessment of unilateral upper limb function for children with hemiplegic cerebral palsy. The American Journal of Occupational Therapy. 65(4): 378-383. https://doi.org/10.5014/ajot.2011.001222

20. Khalili MA, Pahlevanian AA. Evaluation of spasticity using the Ashworth Scale with Intermediate Scores (ASIS). Iranian Rehabilitation Journal. 2010; 8(2): 21-25.

21. Nakhostin-Ansari N, Naghdi S, Moammeri H, Jalaie S. A comparative study on the inter-rater reliability of the Ashworth scales in assessment of spasticity. Acta Medica Iranica. 2006; 44(4): 246-250.

22. Heidari M, Abootalebi S, Hosseini S. Validity of Modified Ashworth Scale as a measure of wrist spasticity in stroke patients. Iranian Rehabilitation Journal. 2011; 9(1): 26-30.

23. Patrick E, Ada L. The Tardieu Scale differentiates contracture from spasticity whereas the Ashworth Scale is confounded by it. Clin. Rehabil. 2006; 20: 173-182. https://doi.org/10.1191/0269215506cr922oa

24. da Silva Lima LA. [Relationship between the level of implementation, control of body and type of mobility in children and teenagers with cerebral palsy] [bachelor's thesis]. São Paulo: Federal University of São Paulo; 2018.

25. Balzer J, van der Linden ML, Mercer TH, van Hedel HJA. Selective voluntary motor control measures of the lower extremity in children with upper motor neuron lesions: a systematic review. Developmental Medicine and Child Neurology. 2017; 59(7): 699-705. https://doi.org/10.1111/dmcn.13417

26. Hanna SE, Bartlett DJ, Rivard LM, Russell DJ. Reference curves for the gross motor function measure: percentiles for clinical description and tracking over time among children with cerebral palsy. Phys Ther. 2008; 88(5): 596-607. https://doi.org/10.2522/ptj.20070314

27. Eliasson A, Krumlinde-Sundholm L, Rösblad B, Beckung E, Arner M, Öhrvall AM, et al. The Manual Ability Classification System (MACS) for children with cerebral palsy: scale development and evidence of validity and reliability. Developmental Medicine and Child Neurology. 2006; 48(7): 549-554. https://doi.org/10.1111/j.1469-8749.2006.tb01313.x

28. Morris C, Kurinczuk J, Fitzpatrick R, Rosenbaum P. Reliability of the manual ability classification system for children with cerebral palsy. Developmental Medicine and Child Neurology. 2006; 48(12): 950-953. https://doi.org/10.1111/j.1469-8749.2006.tb01264.x

29. Öhrvall AM, Eliasson AC. Parents and therapists perceptions of the content of the Manual Ability Classification System, MACS. Scand J Occup Ther. 2010; 17(3): 209-216. https://doi.org/10.3109/11038120903125101

30. Jeevanantham D, Dyszuk E, Bartlett D. The manual ability classification system: a scoping review. Pediatr Phys Ther. 2015; 27(3): 236-241. https://doi.org/10.1097/PEP.0000000000000151

31. Wang TN, Liang KJ, Liu YC, Shieh JY, Chen HL. Psychometric and clinimetric properties of the Melbourne Assessment 2 in children with cerebral palsy. Arch Phys Med Rehabil. 2017; 98(9): 1836-1841. https://doi.org/10.1016/j.apmr.2017.01.024 
32. Bower E. Using the Assisting Hand Assessment and the Mini-AHA for clinical evaluation and further research and development. Developmental Medicine and Child Neurology. 2013; 55(11): 1030-1037. https://doi.org/10.1111/dmcn.12229

33. Marsico P, Frontzek-Weps V, Balzer J, van Hedel H. Hypertonia Assessment Tool. J Child Neurol. 2017; 32(1): 132-138. https://doi.org/10.1177/0883073816671681

34. Choi J, Rha DW, Kim SA, Park ES. The dynamic thumb-in-palm pattern in children with spastic cerebral palsy and its effects on upper limb function. Children (Basel). 2020; 8(1): 17. https://doi.org/10.3390/ children8010017

35. Novak I, Morgan C, Fahey M, Finch-Edmondson M, Galea C, Hines A, et al. State of the Evidence Traffic Lights 2019: systematic review of interventions for preventing and treating children with cerebral palsy. Curr Neurol Neurosci Rep. 2020; 20(2): 3. https://doi.org/10.1007/s11910-020-1022-z

36. Novak I, Honan I. Effectiveness of paediatric occupational therapy for children with disabilities: a systematic review. Aust Occup Ther J. 2019; 66(3): 258-273. https://doi.org/10.1111/1440-1630.12573

37. Park EY, Kim WH. Effect of neurodevelopmental treatment-based physical therapy on the change of muscle strength, spasticity, and gross motor function in children with spastic cerebral palsy. J Phys Ther Sci. 2017; 29(6): 966-969. https://doi.org/10.1589/jpts.29.966

38. Tekin F, Kavlak E, Cavlak U, Altug F. Effectiveness of neuro-developmental treatment (Bobath Concept) on postural control and balance in cerebral palsied children. J Back Musculoskelet Rehabil. 2018; 31(2): 397403. https://doi.org/10.3233/BMR-170813

39. Swierczyńska A, Kłusek R, Jaworek M. Physical and other methods therapy of the spasticity in children. Przegl Lek. 2007; 64(11): 974-977. 